\title{
Marginalisasi Ideologi Tri Hita Karana Pada Media Promosi Pariwisata Budaya Di Bali
}

\author{
Anak Agung Gde Bagus Udayana \\ Jurusan Desain Komunikasi Visual, Fakultas Seni Rupa dan Desain, \\ Institut Seni Indonesia Denpasar, Indonesia \\ E-mail: udayana1973@yahoo.co.id
}

Pariwisata budaya yang dikembangkan di Bali diatur dalam Peraturan Daerah Provinsi Bali Nomor 2, Tahun 2012 tentang Kepariwisataan Budaya Bali yang menekankan pentingnya tri hita karana dalam pengembangan pariwisata di Bali. Oleh karena itu, idealnya segala aktivitas pengembangan pariwisata budaya di Bali, termasuk promosi pariwisata benar-benar menunjukkan aplikasi falsafah tri hita karana. Tujuan jangka panjang penelitian ini, terwujudnya media promosi pariwisata budaya Bali yang benar-benar mengimplementasi ideologi tri hita karana. Terkait dengan tujuan ini, target khusus yang hendak dicapai adalah upaya penggambaran marginalisasi ideologi tri hita karana dalam media promosi pariwisata budaya Bali.

Metode yang digunakan untuk mencapai tujuan dan target tersebut, berupa wawancara mendalam dan pengamatan serta penggunaan dokumen. Wawancara dilakukan dengan pihak terkait, seperti Dinas Pariwisata Provinsi Bali, Dinas Pariwisata Kota Denpasar, Kabupaten Badung, Tabanan, dan Gianyar, serta perusahaan di bidang pariwisata maupun di bidang disain grafis di Bali. Pengamatan dilakukan terhadap billboard yang terkait dengan pariwisata serta dokumen berupa foto, brosur, leaflet, dan iklan tabloid yang mempromosikan pariwisata dan diproduksi oleh para pihat terkait tersebut di atas.

Berdasarkan hasil analisis data dapat disimpulkan Based on the result of analysis bahwa yang memarginalkan ideologi tri hita karana pada media promosi pariwisata budaya di Bali adalah ideologi kapitalisme dan ideologi dualisme kultural. Hal ini terjadi karena pembuatan media promosi pariwisata pada dasarnya bertujuan untuk meningkatkan jumlah wisatawan yang mengunjungi objek yang dipromosikan. Tentu saja tujuan itu berujung pada peningkatan perolehan keuntungan atau uang. Implikasi utama media promosi pariwisata budaya Bali yang ideologi tri hita karana-nya termarginalkan pada citra Bali sebagai daerah pariwisata adalah bahwa Bali tercitrakan sebagai daerah budaya pariwisata dan bukan pariwisata budaya.

\section{Marginalization Of The Ideology Of Tri Hita Karana On Media Promotion Of Cultural Tourism In Bali}

The cultural tourism in Bali is regulated in the Local Regulation of Bali Province Number 2 of 2012 concerning Bali Cultural Tourism which emphasizes the importance of tri hita karana in its development. Therefore, ideally, all the activities related to the development of cultural tourism in Bali, including its promotion, should show the implementation of the philosophy of tri hita karana. The long term goal of this research, the establishment of tourism promotion of Balinese culture media that actually implement the ideology of tri hita karana. Related to this goal, specific targets to be achieved is a depiction of marginalization efforts tri hita karana ideology in the media promotion of cultural tourism in Bali.

The method used to achieve the objectives and targets, are interviews, observations and documents. Interviews were conducted with related parties, such as the Bali Provincial Tourism Office, Tourism Office of Denpasar, Badung, Tabanan and Gianyar, as well as companies in the tourism as well as in the graphic design field in Bali. Observations were made on billboards related to tourism as well as documents such as photos, brochures, leaflets and advertising tabloid that promote tourism and related companies . 
Based on the results of data analysis can be concluded that the ideology of tri hita karana in the media of promotion of cultural tourism in Bali has been marginalized by the ideology of capitalism and the ideology of cultural dualism. This happens because the media making the promotion of tourism was primarily aimed at increasing the number of tourists visiting the attractions being promoted. Of course, that goal led to an increase of the profit or money. The main implications of media of promotion of cultural tourism of Bali whose its ideology of tri hita karana has been marginalizd in the image of Bali as a tourist area is that Bali has an image as the area of tourism culture rather than cultural tourism.

Keywords : Cultural tourism, marginalization, ideology and media implications of tourism promotion

Proses Review : 15 Januari - 5 Februari 2017, Dinyatakan Lolos : 6 Februari 2017

\section{PENDAHULUAN}

Pariwisata budaya yang dikembangkan di Bali diatur dalam Peraturan Daerah Provinsi Bali Nomor 2, Tahun 2012 tentang Kepariwisataan Budaya Bali, khususnya Pasal 1 angka 14 menegaskan bahwa "Kepariwisataan Budaya Bali adalah kepariwisataan Bali yang berlandaskan kepada Kebudayaan Bali yang dijiwai oleh ajaran Agama Hindu dan falsafah Tri Hita Karana". Hal ini menekankan pentingnya tri hita karana dalam pengembangan pariwisata di Bali. Oleh karena itu, idealnya segala aktivitas pengembangan pariwisata budaya di Bali, termasuk promosi pariwisata benar-benar menunjukkan aplikasi falsafah tri hita karana, bahwa keharmonisan hubungan manusia-Tuhan (parhyangan), manusia-manusia (pawongan), dan manusia-lingkungan alam (palemahan) sangat penting untuk mencapai kesejahteraan.

Seperti yang disampaikan pengamat sosial Dasi Astawa di harian Bali Post bahwa keberadaan reklame di Kota Denpasar dinilai tidak mencerminkan kota berwawasan budaya. Keberadaan iklan yang tidak tertata ini telah menimbulkan polusi visual (BaliPost,18/08/2012:2). Tampilan visualisasi juga terlihat kurang menunjukkan identitas budaya Bali, seperti billboard Bali Bird Park terlihat tidak menunjukkan ideologi tri hita karana, yang terpasang di jalan Airport Ngurah Rai, Kabupaten Badung. Oleh karena itu, sebagai suatu ideologi, tri hita karana terlihat telah termarginalisasi dalam media promosi pariwisata budaya Bali.

Pembuatan promosi pariwisata Bali yang mencerminkan falsafah tri hita karana sangat memungkinkan.
Keindahan Bali dalam konteks ini semestinya digambarkan dengan keindahan yang bernuansa budaya Bali berlandaskan Tri hita karana yang berintikan keharmonisan. Misalnya dalam rangka menonjolkan pariwisata sawah, maka media promosi menunjukkan alam sawah yang di dalamnya terlihat keharmonisan secara menonjol, baik keharmonisan dalam hubungan manusia dengan alam, manusia dengan manusia maupun manusia dengan Tuhan. Namun, produk yang hendak dipromosikan harus dapat ditunjukkan dalam keindahan tersebut, seperti foto sawah lengkap dengan aktivitas manusia Bali yang sedang melakukan upacara keagamaan secara kolektif yang mencerminkan keharmonisan sosial, sedang melakukan persembahyangan di sawah, misalnya brosur calendar of event Dinas Pariwisata Provinsi Bali tahun 2014 (lampiran 9). Dengan demikian, sawahnya tampak indah yang di dalamnya terdapat aktivitas yang mencerminkan tri hita karana, tidak hanya menampilkan foto sawah tanpa ada aktivitas keharmonisan. Dalam konteks ini para penggagas dan desainer harus kreatif atau sudah memiliki konsep perancangan yang mencerminkan tri hita karana dalam proses pembuatan media-media promosi, seperti brosur, leaflet, folder, iklan majalah atau tabloid.

Namun fakta menunjukkan bahwa promosi pariwisata budaya Bali telah dilakukan pada media massa, termasuk media cetak, seperti brosur, iklan majalah atau tabloid, leaflet, dan folder tetapi aspek ideologi tri hita karana dalam tampilannya termarginalisasi. Marginalisasi dalam Kamus Besar Bahasa Indonesia (2008:879) diartikan sebagai "meminggirkan". Menurut Piliang (2003: 211), elemen-elemen marginal dengan menempatkannya 
di pinggir gambar. Dengan demikian, marginalisasi ideologi tri hita karana dalam hal ini dapat diartikan sebagai peminggiran atau pengabaian ideologi tersebut dalam tampilan visual media promosi pariwisata budaya Bali.

Adapun materi media promosi itu adalah berupa folder (sebanyak sebelas buah), leaflet (sebanyak empat buah), brosur (sebanyak sebelas buah), iklan majalah (sebanyak sepuluh buah) atau tabloid (sebanyak sepuluh buah), billboard (sebanyak empat buah) sehingga total keseluruhannya sebanyak lima puluh buah selama tahun 2013 sampai dengan 2014. Media-media ini dipilih sebagai objek kajian dalam penelitian karena mengandung kebaruan atau mutakhir, selalu menampilkan desaindesain yang baru setiap tahun dan adanya indikasi memarginalisasi Tri Hita Karana.

Media adalah realitas yang telah dikonstruksi dalam bentuk wacana yang bermakna. Dapat dikatakan bahwa pada dasarnya isi media promosi pariwisata budaya Bali merupakan konstruksi berbentuk wacana yang bermakna tentang pariwisata budaya di Bali. Sebagaimana dikemukakan oleh Althusser (2008) wacana adalah ideologi dalam praktik, tidak ada wacana tanpa ideologi dan tidak ada ideologi tanpa wacana. Bertitik tolak dari pemikiran ini, maka media promosi pariwisata budaya Bali dapat dilihat sebagai wacana yang mencerminkan ideologi tertentu. Oleh karena itu, sebagaimana tercermin pada judul penelitian ini, bahwa fokus penelitian ini adalah ideologi pada media promosi pariwisata budaya Bali.

Berdasarkan fakta-fakta serta pemahaman tentang media, wacana, ideologi dan hubungan satu dengan yang lainnya, maka dapat diformulasikan beberapa dugaan. Pertama, bahwa termarginalisasinya ideologi tri hita karana pada media promosi pariwisata budaya Bali berkaitan dengan ideologi yang ada di balik media promosi pariwisata budaya Bali tersebut. Kedua, media promosi pariwisata budaya Bali yang memarginalkan ideologi tri hita karana berimplikasi dalam pencitraan Bali sebagai daerah pariwisata budaya. Mengingat ini merupakan dugaan, betapapun logisnya tentu saja masih perlu dibuktikan kebenarannya melalui penelitian yang mengkaji masalah yang berkaitan dengan dugaan tersebut.

\section{METODE PENELITIAN}

Penelitian ini menggunakan pendekatan penelitian kualitatif dengan penekanan pada penggalian, penjelasan, dan pendeskripsian pengetahuan secara deskriptif, holistik, dan interpretatif mengenai hal-hal yang berkaitan dengan tujuan penelitian ini. Pelaksanaan penelitian ini dilakukan di Kota Denpasar, Kabupaten Badung, Kabupaten Gianyar, dan Kabupaten Tabanan. Lokasi ini dipilih karena di daerah ini banyak terdapat usaha pariwisata yang menerbitkan media promosi.

Informan dalam penelitian ini adalah para partisipan, baik dalam proses membangun gagasan maupun pengerjaan media promosi pariwisata budaya Bali. Penentuan informan dalam penelitian ini dilakukan secara purposif dan snowball. Informan dalam hal ini terdiri atas Kepala Dinas Pariwisata Provinsi Bali, Kabupaten Gianyar, Kabupaten Tabanan, Kabupaten Badung, dan Kodya Denpasar; serta desainer/praktisi dibidang desain komunikasi visual, Badan Promosi Pariwisata Daerah (BPPD) Bali, dan Gabungan Industri Pariwisata Indonesia (GIPI) Bali.

Jenis data yang digunakan dalam penelitian ini adalah data kualitatif berupa folder, leaflet, brosur, iklan majalah atau tabloid, billboard, sehingga keseluruhannya berjumlah lima puluh buah terdiri atas informasi hotel, objek wisata, dan restoran yang dibuat oleh Dinas Pariwisata Provinsi Bali, Kabupatern Tabanan, Badung, Gianyar, Kota Denpasar, dan pihak swasta. Media promosi ini dipilih karena (1) merupakan produk mutakhir (2013--2014) selama itu selalu menampilkan desain-desain yang baru setiap tahun, (2) adanya indikasi memarginalisasi tri hita karana.

Sesuai dengan pendapat Moleong (2011:4), instrumen utama (primer) penelitian ini adalah peneliti sendiri. Namun mengingat keterbatasan kemampuan peneliti sendiri, maka digunakan pula instrumen tambahan, antara lain pedoman wawancara, alat perekam suara, kamera, dan alat tulis. Pedoman wawancara yang dimaksud dalam hal ini mengacu kepada pendapat Koentjaraningrat (1980:144), bahwa "catatan yang mengandung daftar dari pokok-pokok hal untuk ditanyakan itulah yang disebut pedoman wawancara atau interview guide". 
Pokok-pokok hal yang perlu ditanyakan itu tentu saja tidak dapat dilepaskan dari rumusan masalah dan tujuan penelitian ini. Dengan menggunakan instrumen penelitian tersebut dapat diharapkan tercapai perolehan data dan/atau informasi yang dianggap cukup untuk menjawab permasalahan dan tujuan penelitian yang dikaji dalam penelitian ini.

Metode dan teknik pengumpulan data yang digunakan dalam penelitian ini meliputi metode dan teknik observasi, wawancara, dan penggunaan dokumen. Sedangkan analisis data dalam penelitian ini dilakukan dengan mengikuti prosedur analisis data kualitatif sebagaimana dikemukakan oleh Miles dan Huberman (1992:19-20) yakni melakukan reduksi data, penyajian data sementara, penafsiran data, dan menarik simpulan. Kegiatan pengumpulan data, reduksi data, penyajian data, penafsiran data, dan penarikan kesimpulan dalam hal ini dilakukan secara ulang-alik, artinya, rangkaian kegiatan itu dilakukan tidak hanya satu kali tahapan langsung jadi. Hasil pengumpulan data tahap awal direduksi, disajikan, ditafsirkan, dan ditarik kesimpulan sementara. Namun jika semuanya itu dipandang belum cukup untuk menjawab rumusan masalah yang dikaji dalam penelitian, maka hal serupa kembali dilakukan secara terus menerus sampai diperoleh hasil akhir berupa data atau informasi yang dianggap memadai untuk menjawab rumusan masalah yang dikaji dalam penelitian ini.

Analisis data seperti itu dilakukan secara dekonstruktif, yakni mengikuti langkah-langkah metodologis dekonstruksi sebagaimana dikemukakan oleh Lubis (2014 : 47), yang meliputi tiga tahap. Tahap pertama, yaitu tahap verbal, adalah tahap yang sama dengan pembacaan kritis dengan pencarian paradoks dan kontradiksi dalam teks. Pembacaan ini mencoba melawan teks sehingga dimungkinkan melahirkan makna baru teks. Tahap ini juga dapat membedakan apa yang dinyatakan pada teks dan apa yang tidak dinyatakan. Tahap kedua, yaitu tahap yang mencoba mencari makna yang lebih dalam pada keseluruhan teks.

Penyajian hasil penelitian ini dilakukan dengan mengikuti sistematika daftar isi yang disusun sebelumnya sesuai dengan formulasi permasalahan yang dikaji. Penjabaran hasil analisis data atau informasi dilakukan dengan mendeskripsikan kata-kata dan ungkapan-ungkapan serta dengan menyajikan hasil penelitian dalam bentuk gambar.

\section{HASIL PENELITIAN}

Hasil analisis ini menunjukkan bahwa media promosi pariwisata berupa brosur, folder, leaflet, iklan tabloid/majalah, dan billboard memang bermuatan ideologi. Hal ini sejalan dengan pendapat Karl Marx sebagaimana dikemukakan oleh Halim (2013:45) bahwa "komodifikasi merupakan kata kunci yang dikemukakan oleh Karl Marx sebagai 'ideologi' yang bersemayam di balik media". Media dengan muatan ideologi dapat diposisikan sebagai teks atau wacana berisi warna, gambar/ilustrasi, kata/kalimat yang merupakan satu kesatuan dalam media yang bersangkutan. Satu kesatuan tersebut mengandung pesan tertentu yang berintikan jargon atau manuver tertentu. Oleh karena itu, untuk memahami ideologi yang ada di balik media, termasuk media promosi pariwisata budaya Bali, komponen-komponen media berupa gambar, warna, dan kalimat tersebut perlu dicermati secara saksama.

\section{Ideologi Kapitalisme}

Pengertian ideologi pasar dalam hal ini merujuk pada pendapat para ahli sebagaimana dipaparkan oleh, Atmadja (2010: 75-76) bahwa karakteristik ideologi pasar atau yang disebut juga agama pasar mengacu pada gagasan yang tidak saja berbeda tetapi sekaligus juga bertolakbelakang dengan karakteristik agama Hindu yang merupakan sumber ideologi Tri Hita Karana. Hal ini dapat dilihat pada beberapa hal, yaitu 1) agama Hindu memuja kekuatan adikodrati yang disebut brahman, Tuhan atau dewa sebagai personifikasinya, maupun roh leluhur; sedangkan ideologi pasar atau agama pasar memuja uang; 2) agama Hindu menekankan pada pengendalian nafsu, sedangkan ideologi pasar merangsang nafsu agar terus tumbuh dan berkembang subur; dan 3) dalam agama Hindu, tujuan hidup manusia adalah mewujudkan kesejahteraan, baik di alam sini maupun di alam sana sehingga spiritualitas agama sangat utama; sedangkan dalam ideologi pasar, penekanannya adalah pada kenikmatan duniawi sehingga manusia terjerat pada materialisme, individualisme, sekularisme, otonomisme. Materialisme dalam hal ini dapat diartikan sebagai gagasan yang mengutamakan materi, 
termasuk uang dan benda-benda berharga lainnya. Individualisme diartikan sebagai gagasan yang mengutamakan diri sendiri, baik secara individual maupun kelompok tertentu. Jadi dalam melakukan tindakan, yang diutamakan adalah perolehan materi bagi pelakunya sendiri. Selanjutnya, sekularisme kurang mengutamakan spiritualitas agama; dan otonomisme mengacu pada kebebasan untuk mengatur segala hal yang berkaitan dengan kepentingan diri sendiri.

Karakteristik ideologi pasar sebagaimana dipapaprkan di atas bisa terekspresi dalam tujuan yaitu menjual sesuatu produk. Aktivitas menjual bisa dilakukan melalui media promosi, termasuk media promosi pariwisata. Apa yang ditampilkan dalam media promosi itu tidaklah sekadar ditampilkan, melainkan memuat harapan menjual berdasarkan prinsip kapitalisme, yakni memperoleh keuntungan. Prinsip kapitalisme menekankan bahwa apapun adalah barang dagangan, dan karena itu semuanya harus dijual. Jika alam yang ditampilkan dalam media itu, maka alampun sudah bergeser fungsinya menjadi barang komoditas, atau berfungsi sebagi produk yang bernilai tukar untuk memperoleh uang. Begitu pula dengan objek-objek berupa wujudwujud kebudayaan. Hal ini dapat dicermati pada beberapa media promosi pariwisata budaya Bali berupa iklan tabloid, iklan majalah, brosur. Berkenaan dengan hal ini, iklan tabloid sebagaimana disajikan pada gambar 3.1 di bawah ini menarik untuk dicermati.
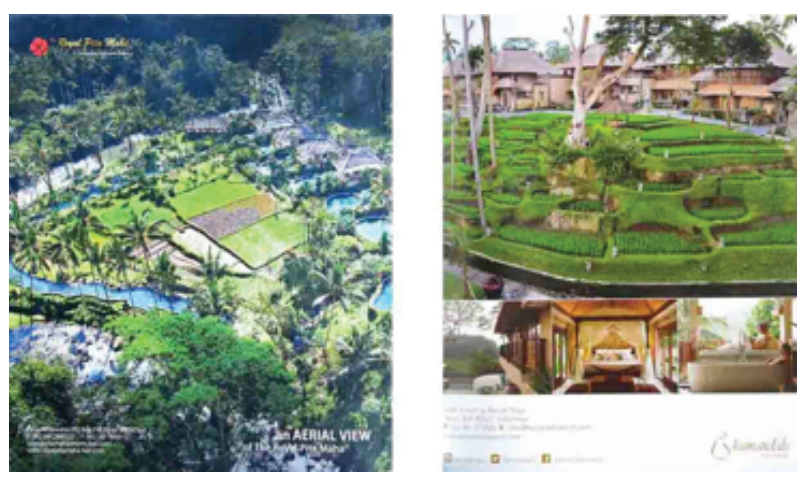

Gambar 1. Keindahan alam pada Media Promosi Royal Pita Maha resort dan Kamandalu resort and spa.

Sumber: Iklan majalah "10 Years 11-12 Oct 2013 Ubud Writers \& Readers Festival Through Darkness to Light, Habis Gelap Terbitlah Terang"
Gambar 1 secara jelas, menunjukkan hamparan sawah dan bangunan villa yang ada di sekitar sawah tersebut. Gambar ini dapat dikatakan tidak mencerminkan Tri Hita Karana karena tidak ada manusia di dalamnya, padahal kehadiran manusia dalam konteks ideologi Tri Hita Karana merupakan hal yang mutlak.

Dilihat dari sudut fungsinya dalam konteks mata pencaharian, sawah adalah lahan untuk bercocok tanam padi yang merupakan mata pencaharian petani yang bersangkutan. Sementara itu, sawah juga merupakan wilayah yang dimiliki oleh organisasi sosial tradisional para petani yang bernama subak. Sebagai suatu organisasi sosial petani, subak menganut ideologi Tri Hita Karana yang dalam peraturannya (awig-awig subak) biasanya dicantumkan sebagai landasan ideal organisasi subak. Dalam konteks Tri Hita Karana, sawah merupakan wujud dari palemahan atau lingkungan alam yang ada di wilayah subak. Mengingat sawah sebagai bagian dari subak serta sebagai salah satu komponen Tri Hita Karana, maka dapat dikatakan keberadaan sawah itu berfungsi sebagai sarana untuk melakukan kegiatan dalam rangka mewujudkan kesejahteraan masyarakat, khususnya masyarakat petani yang bersangkutan.

Meskipun sama-sama dalam rangka mewujudkan kesejahteraan, langkah menampilkan sawah yang dikombinasikan dengan villa pada gambar 1 ternyata tampilannya itu bukan untuk mewujudkan kesejahteraan petani pemilik sawah yang berangkutan, melainkan bagi pengusaha pariwisata atau yang dikenal sebagai kapitalis. Dikatakan demikian, mengingat tampilan sawah dalam hal ini berkaitan dengan promosi pariwisata. Agar media promosi pariwisata ini menarik bagi wisatawan maka tampilan sawah yang merupakan unsur tradisional itu dikombinasikan dengan tampilan villa yang merupakan suatu produk yang bersifat modern. Ini berarti tampilan yang bersifat kombinantif itu diupayakan agar para wisatawan tertarik untuk berkunjung dan tinggal di villa tersebut. Dengan demikian sawah dan villa itu diharapkan bahkan diyakini akan berfungsi sebagai komoditas yang bernilai jual atau bernilai ekonomis. Dalam konteks inilah ideologi pasar secara implisit terlihat berada di balik media promosi pariwisata dengan tampilan seperti tampak pada gambar 1 di atas. 
Selain tercermin pada gambar 1 sebagaimana disajikan di atas, ideologi pasar juga terlihat pada gamabar 3.2 di bawah yang merupakan sebuah iklan majalah yang dibuat oleh Bali Zoo dan ditampilkan pada majalah "10 Years 11-12 Oct 2013 Ubud Writers \& Readers Festival Through Darkness to Light, Habis Gelap Terbitlah Terang”. Iklan tersebut memvisualisasikan foto seorang wanita bule sedang memandikan gajah di suatu tempat dekat pura.

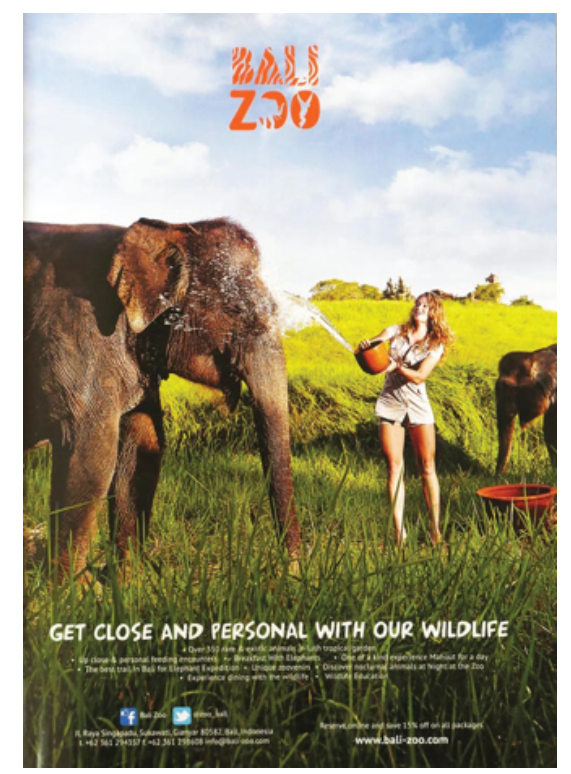

Gambar 2. Penggunaan model wanita asing pada iklan Bali Zoo

Sumber: iklan majalah "10 Years 11-12 Oct 2013 Ubud Writers \& Readers Festival Through Darkness to Light, Habis Gelap Terbitlah Terang"

Gambar 2 ini menarik untuk disoroti dari perspektif Tri Hita Karana yang di dalam Perda Provinsi Bali no.2 Tahun 2012 tentang Pariwisata Budaya Bali diposisikan sebagai falsafah yang patut diacu dalam pengembangan pariwisata di Bali. Sebab, gambar 2 tersebut di atas terlihat tidak mencerminkan identitas Bali yang dilandasi Tri Hita Karana. Hal ini dapat diketahui terutama dari informasi yang diberikan oleh Public Relations Excecutive objek wisata Bali Zoo, Emma Chandra, berikut ini.

"Dalam pemotretan gajah ditemani pawang gajahnya, ada yang pegangi, ada yang ngasi makan, ada kaki diedit sedikit, ada banyak orang di belakang layar, tidak gampang dengan binatang" (wawancara, 21 Nopember 2014).
Selain informasi ini informan tadi juga menegaskan bahwa iklan ini dibuat secara sadar dan tidak diilhami oleh Tri Hita Karana, melainkan didasarkan pada potensi pangsa pasar global. Secara lebih lengkap informasinya itu adalah sebagai berikut.

"Model asing digunakan dalam iklan ini karena main market paling banyak Australia, kedua Asian, dan ketiga baru masuk domestik, kenapa kita menggunakan internasional model tujuan agar masuk kesemua. Main market adalah Australia, agar lebih masuk ke main marketnya maka di coba menggunakan model seperti ini. Artwork ini digunakan untuk majalah yang nasional, majalah regional di Asia Pasifik seba gai destination, dan digunakan pada iklan Jet Star in Flight Magazine, artwork seperti ini" (wawancara, 21 Nopember 2014).

Berdasarkan gagasan yang tercermin pada petikan informasi ini maka dapat dikatakan bahwa ideologi pasar merupakan salah satu ideologi yang ada di balik termarginalisasinya ideologi Tri Hita Karana dalam media promosi pariwisata budaya Bali.

Selain itu, petikan informasi tadi juga mencerminkan bahwa pihak Bali Zoo memandang ideologi pasar dijadikan acuan karena lebih menjanjikan ketimbang ideologi Tri Kita Karana dalam konteks pencapaian tujuan promosi objek wisata tersebut. Logikanya adalah bahwa, jika yang disebutnya sebagai "model internasional" itu digunakan maka kalangan internasional dapat diharapkan merasa terketuk untuk meyakini bahwa objek wisata Bali Zoo tidak hanya disenangi oleh kalangan tertentu saja, melainkan oleh kalangan internasional. Dengan demikian, dapat diharapkan jumlah wisatawan yang berkunjung ke objek wisata tersebut meningkat. Namun, sungguhpun demikian, hal itu jelas telah mengabaikan atau meninggalkan budaya Bali sehingga pariwisata di Bali kurang bercorak pariwisata budaya Bali, melainkan lebih bercorak budaya pariwisata, karena selera wisatawan mendominasi corak iklan pariwisata. Hal ini sejalan dengan pendapat Picard (2006), bahwa yang berkembang di Bali bukanlah pariwisata budaya melainkan budaya pariwisata. Hal ini bukanlah merupakan akibat langsung dari pariwisata yang berintikan budaya global, melainkan lebih merupakan akibat dari perbuatan para pihak pembuat iklan yang sudah menganut 
ideologi pasar, suatu ideologi yang merupakan inti dari globalisasi (Steger, 2006). Jadi ideologi pasar tidaklah bekerja dari luar sana, melainkan dari dalam diri para pembuat iklan dalam promosi pariwisata budaya Bali.

Pembuatan iklan yang diilhami ideologi pasar sebagaimana dipaparkan di atas, disadari atau tidak pada dasarnya merupakan penyimpangan terhadap Perda Provinsi Bali no. 2 Tahun 2012. Dengan mengikuti gagasan Piliang (2006), penyimpangan seperti itu bisa terjadi karena pada era globalisasi orang sudah menganut kebudayaan postmodern, sehingga mereka menjadi homo minimalis dengan karakteritik tersendiri, antara lain lebih mengutamakan perolehan ketimbang proses perolehan. Dalam konteks inilah orang bisa melakukan tindakan yang menyalahi aturan atau norma tertentu, asalkan apa yang hendak diperoleh bisa diraih. Hal serupa inilah yang tampak terjadi pula dalam proses pembuatan iklan Bali Zoo tersebut di atas. Namun selama tidak menimbulkan masalah atau tidak ada yang mempermasalahkannya, maka hal seperti itu akan bisa tetap berlangsung. Dengan demikian, pariwisata yang berkembang semakin jauh dari ketentuan aturan yang dinyatakan berlaku. Lebih dari itu, pengabaian terhadap ideologi Tri Hita Karana juga terlihat dengan jelas pada gambar 2 bahwa gajah sebagai representasi lingkungan alam telah tergusur dari habitat aslinya dan menjadi penghuni habitat buatan manusia yang merupakan karantina yang tentu saja memasung kebebasan yang pada dasarnya dimiliki oleh gajah secara alamiah. Jika keharmonisan hubungan manusia-alam (palemahan) merupakan salah satu sila dalam konteks Tri Hita Karana yang dipandang sebagai penyebab kebahagiaan, maka dari perspektif ini, pembuatan iklan pariwisata dengan cara sebagaimana ditampilkan pada gambar 2 kurang memungkinkan untuk mencapai kebahagiaan. Namun dalam kenyataannya justru dengan cara demikianlah para pembuat iklan tersebut memandang atau berharap akan mendatangkan kesejahteraan ekonomi melalui peningkatan masukan finansial yang bersumber dari wisatawan manca negara. Tampaknya harapan itu sebagian atau sepenuhnya telah tercapai, sehingga tidak mengherankan bahwa iklan yang bernuansa ideologi pasar globallah, bukannya iklan yang bernuansa ideologi Tri Hita Karana yang dikembangkan hingga kini.

\section{Ideologi Dualisme Kultural}

Ideologi dualisme kultural dalam hal ini dipahami sebagai pemikiran para pihak terkait dalam proses produksi media promosi pariwisata budaya Bali yang besifat oposisi biner, yaitu membedakan antara budaya barat yang direpresentasikan oleh wisatawan dan budaya timur yang direpresentasikan oleh para pihak terkait dalam promosi pariwisata budaya Bali. Berdasarkan pemikiran bersifat oposisi biner seperti itu, kemasan media promosi pariwisata budaya Bali disesuaikan dengan citra wisatawan dan citra budaya Bali. Dalam konteks ini wisatawan dicitrakan sebagai sosok modern yang telah biasa mengonsumsi hal-hal modern namun memerlukan hal-hal yang tradisional. Sehubungan dengan hal inilah kemasan media promosi pariwisata budaya Bali dimuati dengan unsur-unsur budaya Bali (tradisional). Hal ini tampak antara lain dari media promosi pariwisata budaya berupa brosur yang mengilustrasikan aktivitas pertanian yang menggunakan teknologi pertanian tradisional yang terlihat dalam gambar 3 sebagai berikut.

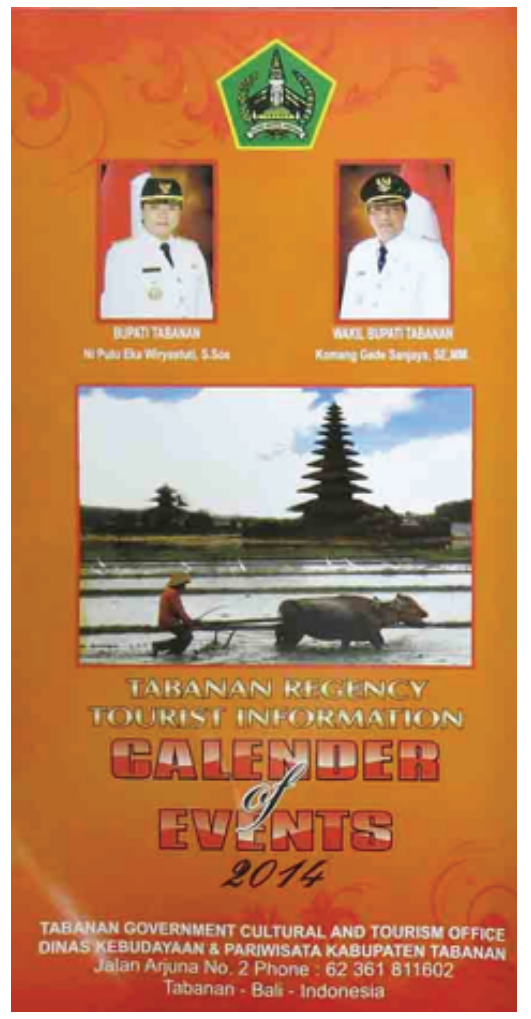

Gambar 3. Pura dan Aktivitas Membajak di Sawah Sumber : Folder Media Promosi Pariwisata Budaya Kabupaten Tabanan 
Gambar 3 secara jelas menunjukkan bahwa ada seseorang laki-laki sedang melakukan aktivitas membajak di sawah dengan peralatan berupa bajak dengan sapi sebagai tenaga penariknya (tradisional), dan bukan traktor (modern) yang sesungguhnya kini lazim dipergunakan oleh para petani Bali. Mencermati ilustrasi foto tersebut di atas, tampaklah bahwa Tri Hita Karana yaitu tiga penyebab kesejahteraan: keharmonisan hubungan manusia-Tuhan, manusia-manusia, dan manusiaalam tidak tercermin atau termaginalisasikan. Dikatakan demikian karena manusia pada ilustrasi tersebut tidak menunjukan hubungannya dengan Tuhan. Meskipun ada gambar pura tetapi aktifitas petani itu tidak berkaitan dengan pura, melainkan hanya berkaitan dengan sawah dan sapi. Hubungan petani dengan sapi dalam hal ini juga dapat dilihat sebagai tidak mencerminkan keharmonisan hubungan antara keduanya. Hubungan antara keduanya lebih bersifat eksploitatif, yakni manusia meeksploitasi sapi untuk kepentingan manusia sendiri. Selain itu proses pembuatan atau pemilihan foto tersebut tidaklah diilhami oleh konsep Tri Hita Karana. Dengan demikian kiranya fakta-fakta ini sudah cukup untuk digunakan sebagai dasar mengatakan bahwa gambar 3 di atas mencerminkan marginalisasi Tri Hita Karana.

Dipergunakannya ilustrasi ini untuk mengemas media promosi pariwisata budaya Bali menunjukkan adanya maksud tertentu. Adapun maksudnya dalam hal ini adalah bahwa masyarakat Bali adalah masyarakat Hindu berbudaya agraris yang bersifat tradisional. Maksud ini juga bermuatan harapan, bahwa unsur budaya agraris yang tradisional ini dapat menarik minat wisatawan sebagai manusia berbudaya modern (barat) untuk berkunjung ke Bali karena di daerahnya sendiri tidak ada budaya tradisional seperti itu.

Gambar 3 menunjukkan seakan-akan letak sawah tersebut berbatasan langsung dengan areal pura. Jika dilihat kenyataannya, gambar pura itu adalah gambar Pura Ulun Danu yang ada di pinggir Danau Beratan, Bedugul. Namun berdasarkan hasil pengamatan diketahui bahwa sesungguhnya di lokasi tersebut tidak ada sawah, apalagi orang membajak sawah. Itulah sebabnya gambar 3 dikatakan menunjukkan adanya manipulasi kenyataan. Menurut informasi dari Kepala Bidang Promosi,
Dinas Kebudayaan dan Pariwisata Kabupaten Tabanan, yakni Ni Ketut Yuliati dalam wawancara 29 Agustus 2014, hal itu dilakukan “.......karena Tabanan merupakan agraris yang ditonjolkan sawah dan pura-pura. Warna yang dipilih didasari oleh indah dan serasi, yang penting tampilannya serasi". Jika disimak, tampaklah petikan informasi ini memuat alasan tertentu atas tindakan mengemas media promosi pariwisata dengan mempergunakan ilustrasi pura dan sawah sebagai komponen media tersebut. Alasannya dalam hal ini adalah bahwa Kabupaten Tabanan merupakan daerah agraris atau masyarakatnya berbudaya agraris dengan mata pencaharian pokok bertani dan beragama Hindu dengan tempat ibadahnya adalah pura. Di satu sisi alasan ini mengambarkan citra Kabupaten Tabanan yang sebagaimana diketahui berjulukan sebagai "lumbung beras". Namun para petani Bali kini amat jarang mempergunakan bajak tradisional, melainkan kebanyakan mempergunakan traktor (teknologi modern). Dengan demikian, gambar 3.3 merupakan konstruksi realita yang pada dasarnya bertolakbelakang dengan realita yang sesungguhnya. Meskipun bertolakbelakang dengan realitas yang sesungguhnya, tampaknya para pihak pembuat gambar 3.3 di atas tetap berkeyakinan bahwa dengan gambar seperti itu orang akan terdorong untuk datang ke Bali dengan harapan dapat menyaksikan secara langsung kenyataan yang telah diilustrasikan pada media promosi berupa brosur/gambar 3 di atas. Dilihat dari perspektif Tri Hita Karana, hasil manipulasi kenyataan sebagaimana tampak pada gambar 3 tidaklah menunjukkan konsep Tri Hita Karana, karena hanya berisi gambar pura dan satu orang membajak sawah yang tidak berkaitan satu sama lainnya.

Selain media promosi pariwisata yang menonjolkan citra budaya tradisional Bali, khususnya di Kabupaten Tabanan sebagaimana tampak pada gambar 3 di atas, ternyata ada pula media promosi pariwisata yang lebih menonjolkan sifat modern. Hal ini dapat dicermati pada iklan yang ditampilkan pada majalah "10 Years 11-12 Oct 2013 Ubud Writers \& Readers Festival Through Darkness to Light, Habis Gelap Terbitlah Terang" sebagaimana tampak pada gambar 4 berikut ini. 

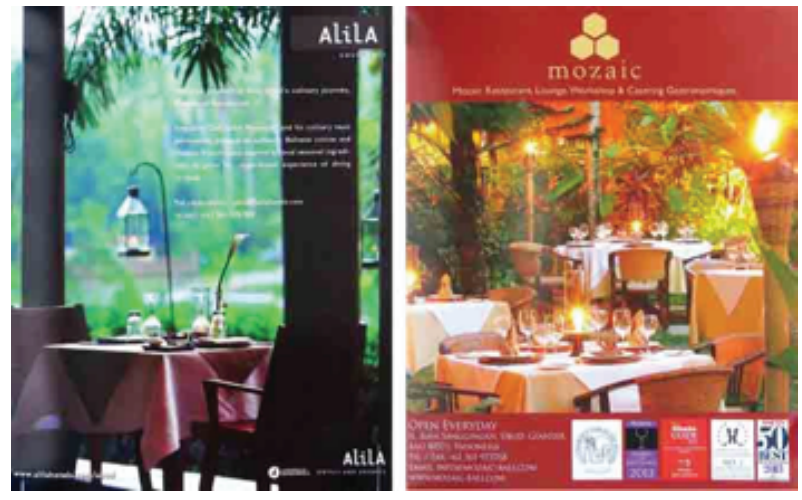

Gambar 4. Media Promosi berupa iklan majalah Alila dan Mozaik Ubud-Bali

Sumber: iklan majalah "10 Years 11-12 Oct 2013 Ubud Writers \& Readers Festival Through Darkness to Light, Habis Gelap Terbitlah Terang"

Gambar 4 di atas dapat diketahui dengan jelas merupakan iklan yang ditampilkan di sebuah majalah dengan memperlihatkan visualisasi berupa foto meja makan di suatu restoran dengan penataan tersendiri. Unsur-unsur yang ditata berupa gelas, minuman wine, mineral water, serbet, dan lain-lain, lengkap dengan teks berbahasa Inggris. Berdasarkan tampilan iklan majalah ini dapat dipahami bahwa dalam rangka melayani wisatawan yang berkunjung ke Bali, para pihak yang bergerak di bidang usaha pariwisata selain mampu menyediakan pelayanan yang bersifat tradisional juga mampu menyediakan pelayanan yang modern sesuai dengan selera wisatawan asing yang merepresentasikan kebiasaan hidup modern. Dengan pelayanan yang lengkap (tradisional dan modern) seperti itulah diharapkan para wisatawan asing tertarik berkunjung ke Bali dan betah berlama-lama di Bali.

Jika disoroti dengan menggunakan perspektif Tri Hita Karana tampaklah pula iklan majalah yang bersifat modern sebagaimana tampak pada gambar 4 di atas sama sekali tidak mencerminkan nuansa ideologi Tri Hita Karana. Dikatakan demikian karena tidak ada unsur manusia apalagi hubungan manusia dengan Tuhan, manusia dengan manusia, dan manusia dengan lingkungan alam. Tampaknya hal ini terjadi karena para pembuat media promosi pariwisata tersebut berorientasi pada ideologi dualisme kultural dalam arti sebagaimana telah dipaparkan di atas. Dengan demikian dapat disimpulkan bahwa ideologi dualisme kultural tersebut merupakan salah satu ideologi yang memarginalkan ideologi Tri Hita Karana dalam media promosi pariwisata budaya Bali.

\section{Implikasi Bali sebagai Daerah Budaya Pariwisata}

Implikasi ini dimaksudkan untuk menyatakan media promosi pariwisata budaya Bali yang memarginalkan ideologi Tri Hita Karana terlihat sebagai media promosi yang mencitrakan Bali sebagai tempat berkembangnya budaya pariwisata, dan bukan pariwisata budaya sebagaimana dikemukakan oleh Picard (2006). Hal ini terlihat dari hasil wawancara dengan pemilik hotel di Sanur berikut ini.

“... karena marketnya sekarang young genera tion, penikmat hidup, nah itu sekarang kita tidak mau bikin bisnis untuk orang tua, karena mereka berapa tahun sih traveling? itu kacamata bisnis saya tidak mau bikin bisnis untuk bisnis orang tua yang 50 tahun keatas saya tidak mau, selalu yang umur 18-20 ...." (wawancara dengan Ida Bagus Agung Parta, 22 Mei 2015)

Petikan informasi ini secara jelas menunjukkan pasar sebagai pusat orientasi dalam pembuatan media promosi pariwisata. Hal ini didasari oleh cara pandang atau perspektif (kacamata) yang digunakan adalah perspektif bisnis pariwisata. Mengingat pada masa kini generasi muda (young generation) dipandang sebagai generasi yang dominan di pasar, maka selera generasi muda itulah yang diacu dalam pembuatan media promosi pariwisata. Proses ini memang logis dalam perspektif bisnis pariwisata, namun informasi tersebut tidak menyebut falsafah Tri Hitas Karana sebagai rujukan.

Jika dicermati, tampaklah proses pembuatan media promosi pariwisata budaya dengan cara yang tidak mencerminkan ideologi Tri Hita Karana sebagaimana dipaparkan di atas pada dasarnya merupakan proses konstruksi realitas berdasarkan kepentingan bisnis pariwisata. Mengingat prosesnya itu merupakan proses konstruksi realitas, maka hasilnya tentu saja bersifat imajiner, dalam arti mencerminkan imajinasi atau citra tentang realita yang berlaku sebagai acuan dalam proses pembuatan media promosi tersebut. Ini berarti citra atas realita terkait dengan objek yang dipromosikan telah dibangun melalui pembuatan media promosi pariwisata yang diharapkan dan sekaligus diyakini 
dapat merangsang kunjungan wisatawan yang semakin banyak. Hasil konstruksinya itu, misalnya berupa folder, billboard, iklan dan lain-lain diyakini sebagai cerminan atas kemampuan mereka mencitrakan Bali sebagai objek wisata yang berdaya tarik wisata tinggi. Menurut pasal 1 ayat 5 UndangUndang RI No 10 tahun 2009 tentang kepariwisataan menyatakan bahwa "daya tarik wisata adalah segala sesuatu yang memiliki keunikan, keindahan, dan nilai yang berupa keanekaragaman kekayaan alam, budaya, dan hasil buatan manusia yang menjadi sasaran atau kunjungan wisatawan". Berdasarkan definisi ini maka dapat dikatakan bahwa media promosi pariwisata budaya Bali yang memarginalkan Tri Hita Karana selama ini dipahami sebagai media promosi pariwisata yang telah mencitrakan Bali sebagai daerah wisata yang unik, indah, mempunyai nilai tersendiri tentang beragam kekayaan, baik kekayaan alam maupun kekayaan budaya. Namun citra ini dibangun dengan menyesuaikan diri terhadap selera wisatawan atau pasar pariwisata, dan bukannya berdasarkan ideologi Tri Hita Karana. Dengan demikian citra Bali dalam hal ini mengambarkan selera wisatawan bukan menggambarkan budaya Bali.

Tampaknya pencitraan yang demikian itu dilandasi pengetahuan, pemikiran, tujuan, dan keinginan serta pembenaran tertentu yang berpusat pada suatu perspektif. Hal ini dapat diketahui dan dicermati pada petikan informasi yang menyatakan "Jadi sekarang ini market tidak usah diajarkan". Tampaknya pernyataan ini bermaksud bahwa melalui media promosi pariwisata, pasar tidak perlu disuguhi objek yang tidak sesuai dengan selera pasar. Hal ini didasari pengetahuan tentang selera pasar, bahwa selera pasar tidak mengidolakan budaya yang autentik. Oleh karena itu dalam rangka membangun citra Bali melalui media promosi harus dan sudah dilakukan evaluasi untuk menentukan objek apa yang perlu dan/atau tidak perlu digunakan sebagai alat pencitraan Bali melalui media promosi pariwisata. Hasil evaluasinya itu menunjukkan bahwa wisatawan tidak begitu menyukai budaya, sehingga penampilan budaya autentik Bali pun dianggap kurang stretegis dalam rangka mendatangkan wisatawan, karena kurang sesuai selera pasar. Karenanya, berdasarkan perspektif bisnis, pencitraan Bali melalui media promosi pariwisata mesti tidak dilakukan dengan mengikuti keinginan untuk mengorbitkan budaya autentik Bali, melainkan dengan menampilkan gambaran tentang fenomena yang disenangi oleh pasar. Hal ini terlihat dari pernyataan dalam petikan wawancarara bahwa "kita orang istilahnya pembisnis ya, kita terbalik, bukan we are the king, tapi market is the king".

Tanpa demikian, tampaknya diyakini tidak akan bisa meningkatkan jumlah kunjungan wisatawan. Keyakinan ini terlihat dari petikan wawancara sebagai berikut.

“.... jadi sekarang kita tebar angket saja di online, sosial group, instragram mana banyak like? oo ternyata lebih banyak suka/like di pantai daripada nonton barong, itu artinya apa? market nya seperti itu sekarang, bisa kita lihat pertunju kan barong, kecak, orang pake bikini di pantai minum pake cocktail, minum bir di pantai kenyataan orang banyak milih kita... sekali lagi ini masalah bisnis. Jadi media promosi ditentu kan oleh market pasar, cara kita menentukan market pasar itu yang young generation" (wawancara dengan Ida Bagus Agung Parta, 22 Mei 2015).

Jika dicermati, informasi ini mencerminkan gagasan bahwa situasi pasar sangat penting untuk dijadikan acuan dalam mengemas media promosi. Artinya, kebutuhan pasar dijadikan patokan dalam menentukan objek-objek yang ditampilkan pada media promosi pariwisata. Tanpa demikian, maka media promosi yang disebarkan akan kurang efektif, atau kurang menggelitik wisatawan untuk berkunjung ke objek yang dipromosikan. Hal ini wajar, mengingat promosi tentulah dilakukan dalam rangka memperoleh keuntungan. Petikan informasi di atas tampak lebih mementingkan keuntungan material atau keuntungan ekonomis daripada keuntungan nonmaterial. Kewajarannya itu dapat lebih dimaklumi lagi karena pembuatan promosi ini merupakan kegiatan industri yang berkaitan dengan pariwisata yang berskala internasional, sedangkan sebagamana dikemukan oleh R. Firth (dalam Koentjaraningrat, 1990 : 188), selain keuntungan material ada pula keuntungan nonmaterial atau keuntungan sosial-budaya dalam aspek perekonomian. Dalam koteks ini, ekonomi industri dan perdagangan internasional dikatakan lebih mementingkan keuntungan material. 
Orientasi pada pasar seperti itulah yang mendorong pembuatan media promosi pariwisata budaya yang justru tidak menampilkan objek yang bernuansa budaya Bali, termasuk yang bernuansa Tri Hita Karana. Misalnya objek berupa pentas seni tari barong yang dikatakan kurang digemarti wisatawan dibandingkan dengan objek berupa kegiatan di pantai, seperti kegiatan minum bir, cocktail di pantai ternyata lebih disukai wisatawan, terutama wisatawan dari kalangan generasi muda. Jadi citra pariwisata budaya Bali dalam hal ini dilihat dari kacamata pasar, bukan dari kacamata budaya Bali. Dilihat dari segi kacamatan pasar, tampaklah citra Bali yang promosi pariwisatanya mengabaikan Tri Hita Karana itu sebagai daerah pariwisata yang mampu menyediakan pelayanan yang sesuai dengan kebutuhan pasar. Kemampuan seperti itu lebih memungkinkan untuk memperoleh keuntungan material.

Tampaknya pemikiran seperti terurai di atas sudah lumrah di kalangan para pihak yang berkecimpung dalam industry pariwisata di Bali. Kelumrahan itu dapat diketahui berdasarkan informasi berikut ini.

"Caranya bagaimana menyampaikannya tergan tung pada karakter masyarakat itu sendiri mana yang ditargetkan oleh produk itu sendiri, kalau dia menujunya ke pasar domistik, cirinya domis tik supaya bisa komunikasi, kalau dia orang Australia cara-cara berpikir orang Australia apa kesukaan orang Australia, gimana mentalmental orang Australia supaya nyambung itu bisa ditangkap langsung. Tapi kalau ini kita sang kutkan dengan Tri Hita Karana, Tri Hita Karana adalah identitas bukan sebetulnya media kita menyampaikan sesuatu kepada masyarakat itu cuma corak kita saja, identitas saja, kalau kita komunikasi dengan Australia apa cocok Tri Hita Karana kita masukan kesana, mungkin dia tidak nangkap apa maksudnya itu" (Wawancara dengan IB Ngurah Wijaya Ketua Bali Tourism Board(BTB)/Gabungan Industri Pariwisata Indo nesia (GIPI) tanggal 14 Agustus 2015).

Pada intinya petikan informasi ini mencerminkan gagasan bahwa corak media promosi harus sesuai dengan selera wisatawan yang hendak disasar. Secara implisit gagasan ini mengandung pendapat bahwa jika wisatawan yang disasar adalah wisatawan domestik maka media promosi yang digunakan adalah media yang menampilkan objek- objek yang sesuai selera wisatawan domestik. Sebaliknya, jika wisatawan yang hendak disasar adalah wisatawan mancanegara, maka media promosi yang dibuat dan digunakan adalah media promosi yang menampilkan objek-objek yang sesuai selera wisatawan mancanegara. Dalam konteks ini, media promosi pariwisata yang mengedepankan objek bernuansa Tri Hita Karana dianggap kurang relevan untuk menyasar wisatawan mancanegara, seperti wisatawan Australia yang dianggap tidak tahu apalagi tertarik dengan Tri Hita Karana.
"Kalau kita komunikasi dengan Australia apa cocok Tri Hita Karana kita masukan kesana, mungkin dia tidak nangkap apa maksudnya itu. Bali ini mau dijual apanya, kalau kita mau jual budayanya target market kita orang budaya itu yang interest dengan budaya kita, kalau kita targetkan dengan orang yang suka sport sdh tidak nyampe, kalau kita mau menyampekan dengan orang bisnis, sudah tidak nyampe. Itu garis besarnya, jangan sampe kita-kita Tri Hita Karana itu dipake sebagai, market itu harus terima ini, ada orang yang tidak bisa terima, kalau kita inginkan orang-orang yang budaya kemari kita cari market yang berbudaya tersebut, yang cari budaya itu" (Wawancara dengan IB Ngurah Wijaya Ketua Bali Tourism
Board(BTB)/Gabungan Industri Pariwisata Indonesia (GIPI) tanggal 14 Agustus 2015).

Berdasarkan inti petikan informasi yang demikian itu maka dapat dikatakan bahwa informan yang bersangkutan memaknai Tri Hita Karana merupakan identitas budaya Bali yang kurang relevan untuk ditampilkan pada medias promosi pariwisata yang hendak menyasar wisatawan, baik wisatawan domestik maupun wisatawan mancanegara. Namun argumentasi atas anggapannya ini adalah karena wisatawan tidak tahu apalagi tertarik dengan $T r i$ Hita Karana. Jadi anggapan ini seakan-akan mengklaim bahwa media promosi pariwisata budaya Bali yang bernuansa Tri Hita Karana tidak memungkinkan untuk menarik perhatian wisatawan. Ini berarti, media promosi pariwisata yang tidak menonjolkan Tri Hita Karana dianggap lebih cocok untuk memangun citra Bali sebagai daerah pariwisata. Padahal media promosi pariwisata budaya Bali yang bernuansa Tri Hita Karana bukan berarti ditujukan untuk memahamkan atau mengajarkan Tri Hita Karana kepada wisatawan, melainkan untuk membuat media promosi yang 
tetap menarik perhatian wisatawan tetapi tetap pula mencerminkan identitas budaya Bali. Lagipula media promosi pariwisata yang berrnuansa Tri Hita Karana bukan tidak mungkin untuk menarik perhatian wisatawan, karena sebagaimana telah dikatakan Tri Hita Karana berintikan keharmonisan hubungan manusia-Tuhan, manusia-manusia, dan manusia-alam. Oleh karena itu, jika media promosi pariwisata budaya Bali bisa dikemas dengan tetap mengandung nilai-nilai Tri Hita Karana berarti media promosi itu mencitrakan Bali yang Bali (bersih, aman, lestari, dan indah), karena nilai keharmonisan seperti itulah yang memungkinkan untuk membangun Bali yang Bali. Tentu saja keharmonisan beserta kebersihan, keamanan, kelestarian, dan keindahan seperti ini pada umumnya didambakan oleh siapapun, termasuk oleh wisatawan. Dengan demikian, persoalannya adalah pada kemampuan membuat media promosi pariwisata budaya Bali yang menarik tetapi bernuansa Tri Hita Karana.

\section{SIMPULAN}

Pertama, ada ideologi pasar di balik fenomena marginalisasi ideologi Tri Hita Karana pada media promisi pariwisata budaya Bali. Ideologi pasar yang ada di balik media promosi pariwisata budaya Bali tercermin dari beragamnya produk media promosi pariwisata budaya Bali. Keberagaman produknya itu terlihat dari jenis media promosi (folder, iklan majalah, dan billboard); dan elemen-elemen visual seperti logo, warna, teks, ilustrasi atau gambar. Walaupun beragam sesungguhnya yang paling dominan/sentral adalah ideologi pasar. Artinya ideologi selain ideologi pasar sebagaimana disebutkan di atas diilhami oleh ideologi pasar yakni ideologi yang mengutamakan perolehan uang.

Kedua, media promosi pariwisata yang ideologi Tri Hita Karana-nya termarginalisasi berimplikasi dalam pencitraan Bali sebagai daerah pariwisata budaya. Implikasinya itu adalah: (1) Bali sebagai daerah budaya pariwisata (bukan pariwisata budaya). Berdasarkan implikasi seperti itu, maka media promosi pariwisata budaya Bali terlihat kurang mendukung upaya menegaskan identitas pariwisata budaya Bali, yaitu pariwisata budaya yang berbasis Tri Hita Karana. Dalam keadaan demikian, citra Bali terlihat sebagai daerah pariwisata budaya yang dikonstruksi melalui proses pembuatan media promosi pariwisata yang secara signifikan didasarkan pada kepentingan bisnis pariwisata.

\section{DAFTAR RUJUKAN}

Alexander, Aur. 2005. "Pascastrukturalisme Michel Foucault dan Gerbang Menuju Dialog antarperadaban". Dalam Mudji Sutrisno dan Hendar Putranto (ed), Teori-Teori Kebudayaan. Halaman 145-161.Yogyakarta : Kanisius.

Althusser, Louis. 2008. Tentang Ideologi : Marxisme Strukturalis, Psikoanalisis, Cultural Studies. Yogyakarta : Jalasutra.

Aminuddin, 2002. "Pendekatan Linguistik Kritis: Roger Flower". Dalam Kris Budiman (penyunting), Analisis Wacana dari Linguistik Sampai Dekonstruksi. Halaman 1-53. Yogyakarta : Penerbit Kanal.

Arisandi, Ni Gst A.D.P. 2011. "Persepsi Masyarakat Desa Beraban tentang Program Siaran Pariwisata Budaya di Bali TV sebagai Media Informasi dan Promosi". Tesis Program Studi Magister Pariwisata, Universitas Udayana.

Baha, Lajar A. 2005. "Jaques Derrida dan 'Perayaan' Kemajemukan”. Dalam Mudji Sutrisno dan Hendar Putranto (ed), Teori-Teori Kebudayaan. Halaman 163-175.Yogyakarta : Kanisius.

Barker, Chris. 2005. Cultural Studies, Teori dan Praktik. Yogyakarta: Kreasi Wacana

Berger, Peter L dan Luckmann, 2012. Tafsir Sosial atas Kenyataan: Risalah Tentang Sosiologi Pengetahuan. (Hasan Basari, Pentj). Jakarta: LP3ES.

Desi, I D S dan Larry, J. 2009. Kajian Penerapan Konsep Barnding Bali pada Media Promosi Dinas Pariwisata budaya Bali tahun 2008. Denpasar: Institut Seni Indonesia Denpasar. 
Faruk, HT, 2002. "Konsep dan Analisis Wacana Althusserean". Dalam Kris Budiman (penyunting), Analisis Wacana dari Linguistik Sampai Dekonstruksi. Halaman 135-153. Yogyakarta : Penerbit Kanal.

Fashri, Fauzi. 2007. Penyingkapan Kuasa Simbol: Apropriasi Reflektif Pemikiran Pierre Bourdieu. Yogyakarta: Juxtapose.

Halim, Syaiful . 2013. Postkomodifikasi Media: Analisis Media Televisi dengan Teori Kritis dan Cultural Studies. Yogyakarta: Jalasutra.

Hamad, Ibnu. 2004. Konstruksi Realitas Politik Dalam Media Massa Sebuah Studi Critical Discourse Analysis terhadap Berita-berita Politik. Jakarta:Granit.

Hamad, Ibnu. 2004. KONSTRUKSI REALITAS POLITIK DALAM MEDIA MASSA(Studi Pesan Politik Dalam Media Cetak Pada Masa Pemilu 1999). Jurnal: Makara, Sosial Humaniora, Vol 8, No.1, April. Halaman 21-32. Jakarta:UI.

Harker, Richard. t.t. "Bourdieu-Pendidikan dan Reproduksi", dalam (Richard Harker, ed.; Pipit Maizier, penerjemah),(Habitus x Modal) + Ranah = Praktik. Halaman 109-138. Yogyakarta : Jalasutra.

Hoed, Benny H. 2008. Semiotik dan Dinamika Sosial Budaya. Depok: Fak Ilmu Pengetahuan Budaya (FIB) UI.

Irawan, Prasetya. 2006. Penelitian Kualitatif dan Kuantitatif Untuk Ilmu-ilmu Sosial. Depok: Departemen Ilmu Administrasi FISIP UI.

Pusat Bahasa. 2008. Kamus Besar Bahasa Indonesia. Jakarta: PT Gramedia Pustaka Utama.

Koentjaraningrat. 1980. "Metode Wawancara". Dalam Koentjaraningrat (ed.). Metode-Metode Penelitian Masyarakat. Halaman 129-157. Jakarta: Penerbit PT Gramedia.

Lubis, Akhyar Yusuf. 2014. Postmodernisme: Teori dan Metode. Jakarta: Rajawali Pers.
Lubis, Akhyar Yusuf. 2014. Teori dan Metodologi Ilmu Penelitian Sosial Budaya Kontemporer. Jakarta: Rajawali Pers.

Mely G. Tan. 1980. "Masalah Perencanaan Penelitian". Dalam Koentjaraningrat (ed.) MetodeMetode Penelitian Masyarakat. Halaman 14-43.Jakarta : PT Gramedia.

Miles, B.B., dan Huberman A.M. 1992. Analisis Data Kualitatif. Jakarta: UI Press

Moleong, Lexy. 2011. Metodologi Penelitian Kualitatif. Bandung: PT Remaja Rosdakarya.

Pemerintah Provinsi Bali. 2012. Peraturan Daerah Provinsi Bali Nomor 2 Tahun 2012 tentang Kepariwisataan Budaya Bali. Denpasar: Provinsi Bali.

Piliang, Yasraf Amir. 2003. Hipersemiotika: Tafsir Cultural Studies Atas Matinya Makna. Yogyakarta: Jalasutra.

Plummer, Ken. 2013. Sosiologi the Basic. Jakarta: PT Raja Grafindo Persada.

Pusat Bahasa. 2008. Kamus Besar Bahasa Indonesia. Jakarta:Pt Gramedia Pustaka Utama.

Pujiriyanto, 2005. Desain Grafis Komputer (Teori Grafis Komputer). Andi: Yogyakarta.

Suriasumantri, Jujun S. 1984. Filsafat Ilmu Sebuah Pengantar Populer. Jakarta: Sinar Harapan.

Takwin, Bagus. 2003. Akar-Akar Ideologi : Pengantar Kajian Konsep Ideologi dari Plato Hingga Bourdieu. Yogyakarta : Jalasutra.

Taylor, Steven dan Bogdan Robert, 1984. Introduction to Qualitative Research Methods. New York : John Wiley \& Sons.

Bali Post. 2012. "Semrawut, Reklame di Denpasar Timbulkan Polusi Visual”. 18 Agustus. Halaman 2. 